\title{
Associations between Integrator, Grower Involvement and Business Performance: Emphasis on Validity \& Reliability
}

\author{
Ahmad Shabudin Ariffin ${ }^{1, *}$, Shahimi Mohtar ${ }^{1} \&$ Halim Mad Lazim ${ }^{1}$ \\ ${ }^{1}$ School Technology Management \& Logistics, College of Business, Universiti Utara Malaysia, Malaysia \\ *Corresponding author: School Technology Management \& Logistics, College of Business, Universiti Utara \\ Malaysia, Malaysia. E-mail: ashabudin@uum.edu.my
}

Received: July 22, 2014

Accepted: September 17, 2014 Online Published: December 10, 2014

doi:10.5430/mos.v2n1p95

URL: http://dx.doi.org/10.5430/mos.v2n1p95

\begin{abstract}
The aim of this study is to explain an investigation over the potential relationships between integrator and grower involvement towards business performance in broiler production. The potential role of employees' skill levels as moderating variable between the aforementioned independent and the dependant variables are discussed. Broiler supply chain practices and its corresponding performance indicators in the form of broiler farming operations are among the important measures in the dependant variable (business performance). Based on the extensive survey of relevant literatures, a research framework is then proposed. The content validity has been done by getting opinion from the experts, namely veterinary officers. Besides that the construct reliability is determined through value from Cronbach's Alpha. The data obtained was satisfactory for content validity and construct validity also fit the model as proposed previously.
\end{abstract}

Keywords: supply chain; broiler; supplier; integrator; involvement and business performance

\section{Introduction}

The Malaysian livestock industry is an important and integral component of the agricultural sector providing employment and producing useful animal protein food for the population, estimated at 28 million people and also to about 5 million people in Singapore. The broiler industry in Malaysia has two types of producers. It comprises commercial farms and conventional farms. Commercial farms that run business on contract farming are associated with integrators while conventional farms belong to independent entrepreneurs. The contracting scheme is more likely to be sustained by its ability to support entrepreneurs than it is by its ability to produce highly competitive. In 2009 there were 3,300 farms in operation carrying a standing population of nearly 186 million broiler chicken products. Of these, $22.9 \%$ are large farms with more than 50,000 broilers per cycle while $26.2 \%$ are medium scale farms carrying 20,000-50,000 broilers per cycle, and the rest are small farms with 20,000 broilers per cycle. Only $9 \%$ of local production was used for further processing. However, processers were increasingly getting supplies from cheaper imported poultry meat for value added processing. In fact, most of poultry supplied for processing were from imports. The main challenge facing the industry is its competiveness, as prior to WTO and AFTA, the broiler industry was highly protected through import bans and quantitative restrictions.

Among all economic activities, agribusiness is developing with great force in the world, stimulated mainly due to increase of the population and demand for food. Agribusiness studies have been the focus of academic research for quite a long time. However, those studies usually have used a theoretical background, connotations, frames of reference and methodologies slightly different from those used in the research on Supply Chain Management (SCM). Although there is extensiveness literature on the business performance of manufacturing companies in the developed countries, whereas, there is limited empirical information about it in Malaysia. The aim of this study is to propose an investigation on the potential relationships between integrator involvements and grower involvement towards business performance in broiler production. The remaining part of this paper is organized as follows: Section 2 reveals an overview of the research problem, section 3 presents comprehensive survey of literature that enables conceptualization of research framework, section 4 depicts proposed research framework. The following section 5 deals with research aims and subsequently section 6 with materials and methods. Section 7 describes expected contributions and finally conclusion of the research is presented in section 8. 


\section{Problem Overview}

Broiler contracting involves the use of improved and standardized technology and production practices. This involves supply of inputs, close contact and training of the contract grower. Protecting this investment (in inputs and training) requires that default by growers and turnover in their ranks should be minimum (Key \& Runsten, 1999). So for the whole process of broiler production, it has crucial variables that need to be addressed empirically.

\section{A. Supply Chain in the Broiler Industry}

Main players normally have a vertically integrated supply chain, operating as integrated producer; owning the majority of all breeding, feed, slaughtering and processing facilities (see Fig. 1) as well as they operate with a wide variety of distribution channels, ranging from super and hyper markets to distributors restaurants, wet markets and groceries.

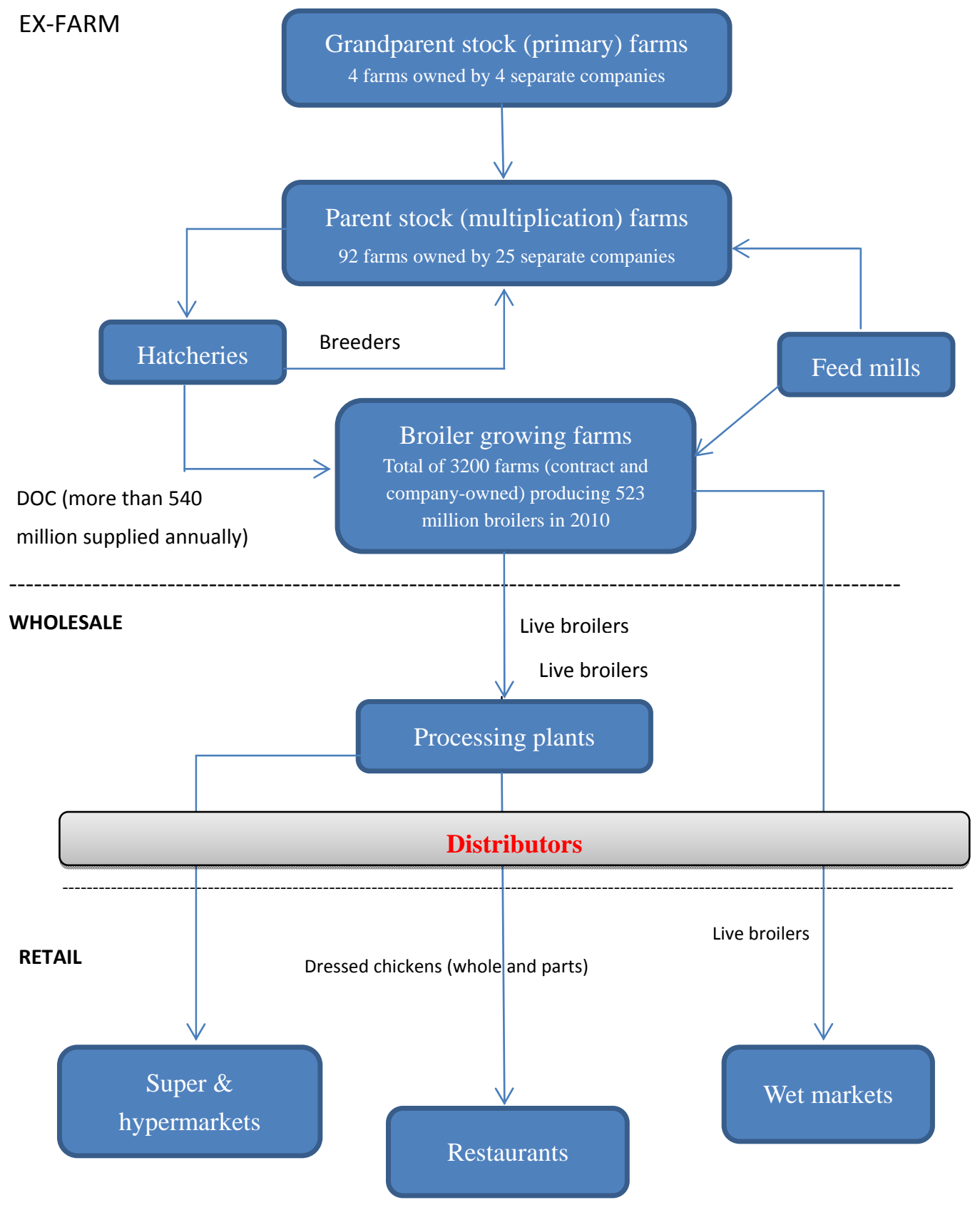

Figure 1. The Vertically Integrated Poultry Production Supply Chain

Source: Review of Domestic Broiler Market: Issues Paper MyCC, 2012 
Vertical production chains consist of a single company controlling all aspects of each stage of production. Hatcheries, farms, feed companies processing plants, harvesting team, distribution, and markets can all be integrated into a single corresponding supply system. In response to shifting conditions in both export and domestic markets, many producers are shifting their production further into these types of vertical systems. Moreover, a select number of firms control the majority of the market. There are some dangers of a few large integrated systems controlling the broiler sector.

\section{B. Contract Farming}

The term "contract farming" generally refers to situations in which a farmer raises or grows an agricultural product for a vertically integrated corporation. There are two parties in a typical contract farming arrangement: the grower and the company (Integrator). Broiler contracts consist of contracting out the growing stage. Integrators recruit large farms (growers) to rear broiler chickens for meat according to contractual guidelines. Farming contracts can also help growers mitigate risks posed by fluctuations of input prices and provide a secure market outlet for their product. The latter is especially important because of the limited facilities that process chickens raised by independent farmers. While current trends are moving producers toward vertical integration, there remain many farms currently under contract or with unused infrastructure from past contracts. Most integrators in Malaysia participated contract farming with growers for broiler production. Consequently, the integrators are always involved in every stage of production. While there are key differences between contract farming and complete vertical integration (e.g. who supervises over important growth stages), most aspects of the supply chain are the same.

\section{Conceptualisation of Research Framework}

\subsection{Integrator Involvement in Product Modularity (PM)}

According to Schilling (2000) PM as a continuum of describing separateness, specificity and transferability of product components in a product system. A product is transferrable if the product components in a product system can be reused by another. It can be separated as it can be disassembled and recombined into new product configurations without loss of functionality Schilling (2000), and specified as the product component has a clear, unique and definite product function with its interfaces in the product system (Ulrich, 1995). If a product has high PM (i.e. modular product design), the product system has separate modules with well-specified interfaces across the modules, such as those found in personal computers. Equally, if a product has low PM (i.e. integrated product design), the product components are highly interlinked without well-specified interfaces across the components, like those found in fine art. It is very difficult for these components to be transferred to other product lines (Lau, 2011). The product modules can be transferred to different product lines and progressive development projects. In this research, we define product modularity as the use of standardized and interchangeable parts or components that enable the configuration of a wide variety of end products.

\subsection{Integrator Involvement in Internal Coordination (IC)}

Recent literature have stated that successful product development can only be achieved if the organization can effectively integrate internal functional units, including marketing, manufacturing, R\&D, and purchasing (Gerwin \& Barrowman, 2002; Clark \& Fujimoto, 1991). Diverse internal integration mechanisms (e.g. cross-functional teams, overlapping, employee involvement, concurrent engineering, collocations, dedicated teams, empowered teams) have been recommended in different phases of NPD (Griffin, 2002; Hargadon \& Eisenhardt, 2000; Zirger \& Hartley, 1994). Occasionally, it is better to improve new products jointly with integrator at an early phase so that their capabilities and new ideas can be fully integrated in the product development (Lau, 2011). Internal partners may assimilate external uncertainties and linkages and, subsequently, extends IC practices to supplier and customer integration (Zhao et al., 2011; Tan and Tracey, 2007; Droge et al., 2004).Thus, this study defines IC as the degree of the coordination among sales and marketing, research and development, and production to inventory management throughout the product development process.

\subsection{Integrator Involvement in Product Innovativeness (PI)}

No consensus on the definition of innovativeness has been made, although it is generally regarded as a measure of discontinuity in the marketing and/or technology factors at both industry and firm levels Calantone, Chan \& Cui, 2006; Garcia \& Calantone, 2002; Danneels \& Kleinschmidt, 2001). A comprehensive literature review conducted by Garcia and Calantone (2002) shows that it is important to consider both marketing and technological perspectives, as well as the macro-level and micro-level, when identifying innovations. Highly-innovative products, offering "new-to-the-world" functions that nobody can rapidly compete with, can improvement first force advantages to earn 
significant market share. They also differentiate existing products by providing technological breakthrough advantages (Lau, 2011). An important part of the research within the new product literature focuses on the effect of PI on product performance (Cooper, 1979; Zirger \& Maidique, 1990; Kleinschmidt \& Cooper, 1991; Cooper \& Brentani, 1991; Song \& Parry, 1997; Song \& Montoya-Weiss, 1998). Even with the widely varying conceptualizations and operationalization of the PI construct Danneels and Kleinschmidt (2001) there are prevailing views arguing that both higher and lower PI increases product performance while the opposite holds true for moderate PI. Based on the above, this study seeks to provide new evidence concerning PI as a phenomenon and extend the empirical literature to the relation between PI and performance. Given the above considerations, the research questions that this empirical study raises, attempt to identify differences, if any, in performance measures at both the product level.

\subsection{Integrator Involvement (II)}

According to Song and Benedetto, (2008); Van Echtelt, Wynstra, Weele \& Duysters (2008) II is recognized as an important way for new product success. In this study, SI is defined as the direct participation of the supplier during the product development processes (Ragatz, Handfield and Scannell, 1997). Suggested by Fliess and Becker (2006); Takeishi (2001) it involves joint product design, process engineering and production operations with key suppliers. II helps secure resources and capabilities, which the manufacturers do not have but essential for product innovation (Grant, 1996). It helps the supplier learn new technology applications while the buyer can actively shape product performance (Athaide \& Klink, 2009).

\subsection{Grower Involvement (GI)}

Suggested by Feng, Sun and Zhang (2010); Brown and Eisenhardt (1995) GI is defined as the direct participation of the customer in the design and development stages of New Product Development (NPD), in which the customer engages in problem solving activities and co-develop the final forms of the product with the manufacturers. It involves joint product design, process engineering, and production operations with key customer. According to Brown and Eisenhardt (1995); Clark and Fujimoto (1991) the early involvement of customers or early customer inputs is essential to develop new products. It facilitates the project teams to recognize new ideas and opportunities while avoiding development delays due to a mismatch of the ideas and the customer needs (Ittner \& Larcker, 1997).

\subsection{Business Performance}

If organizations cannot measure performance, they cannot manage their business (Kaplan \& Norton, 1992). This statement summarizes the necessity of performance to measure, and as direct consequence, and to evaluate their performance (O'Raily, Wathey \& Gelber, 2000). Business performance is measured in many different ways such as innovation, profit and sales, rate of new product development, customer satisfaction, customer retention, operating costs, profitability and return on investment (ROI) (Zack, McKeen \& Singh, 2009). Business performance is also defined as measurable result of the level of attainment of organizations goals Daft and Marcic (2001) or measurable result of the organization's management of its aspects (ISO 1999). In this study, business performance is measured in relations to the supply chain perspective and is accordingly use conventional supply chain measures such as revenues, customer and supplier satisfaction, customer retention, and operating cost. The study also proposes the inclusion of green practices (poultry waste management) in the measurement of business performance.

\section{Proposed Research Framework}

Hypothesis

This section addresses the research hypothesis that need to be tested to achieve the objectives of this research. There were outlined in eight hypotheses as discussed below.

$\mathrm{H}_{1}$ Product modularity is significantly associated with business performance.

$\mathrm{H}_{2}$ Internal coordination is significantly associated with business performance.

$\mathrm{H}_{3}$ Product innovativeness is significantly associated with business performance.

$\mathrm{H}_{4}$ Grower Involvement is significantly associated with business performance.

$\mathrm{H}_{5}$ Managerial Skills will moderate the relationship between Product Modularity and Business Performance.

$\mathrm{H}_{6}$ Managerial Skills will moderate the relationship between Internal Coordination and Business Performance.

$\mathrm{H}_{7}$ Managerial Skills will moderate the relationship between Product Innovativeness and Business Performance. 
$\mathrm{H}_{8}$ Managerial Skills will moderate the relationship between Grower Involvement and Business Performance.

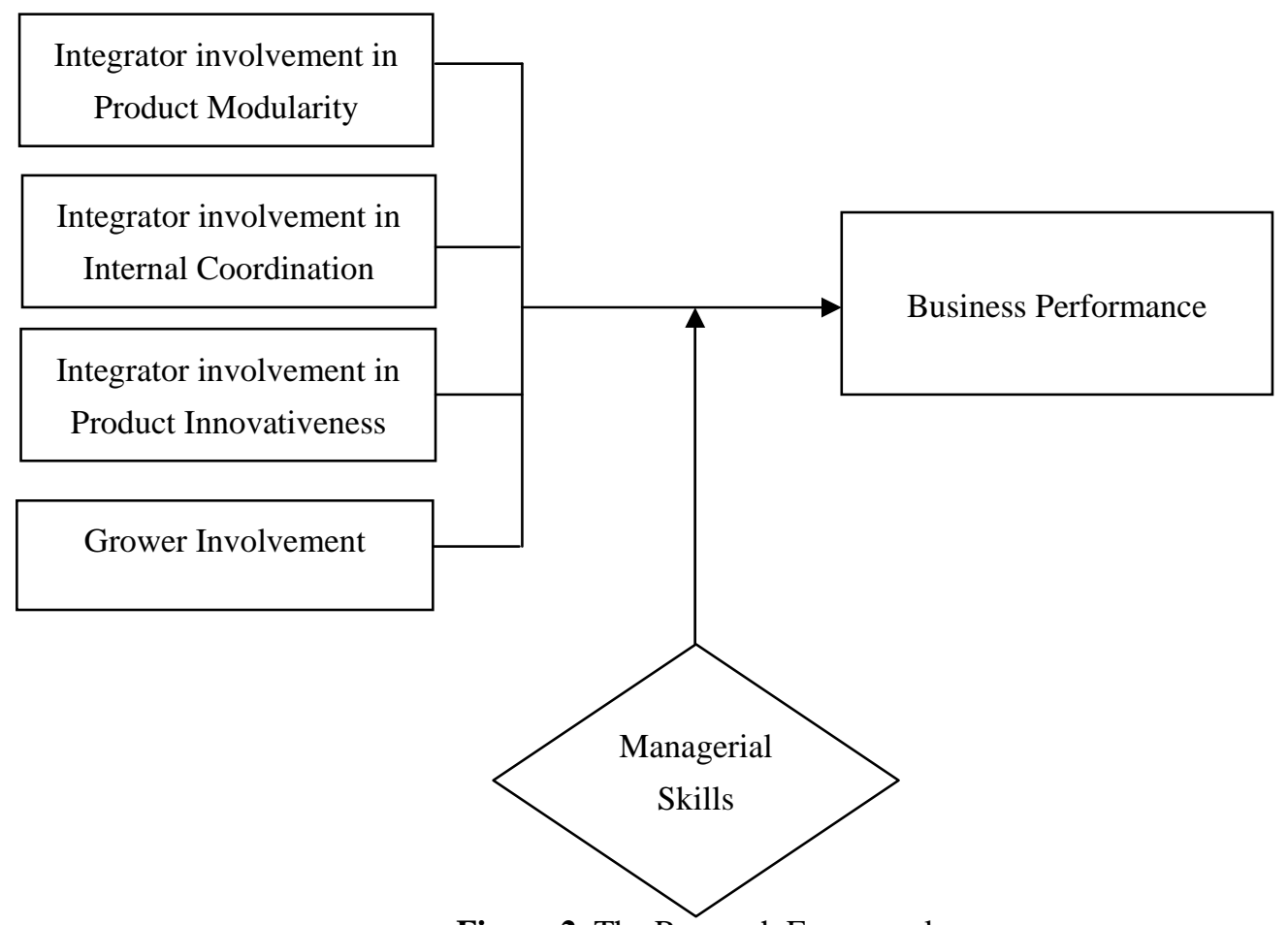

Figure 2. The Research Framework

\section{Research Aims}

This study attempts to answer the following research questions: (1) Are there any relationship between product innovativeness, product modularity and internal coordination variables towards business performance?, (2) What is the variable in the Integrator involvement that has the largest effect on the business performance?, (3) Is there any relationship between grower involvement and business performance?, and (4) is there any moderating effect between integrator involvement, grower involvement and business performance?. Based on these questions, following are the objectives of this study:

i. To identify the relationships between integrator involvement in product innovativeness, integrator involvement in product modularity and integrator involvement in internal coordination variables towards business performance.

ii. To examine which variable in integrator involvement has the largest effect on the business performance.

iii. To determine the relationships between grower involvement and business performance.

iv. To investigate the moderating effect of managerial skills level on the relationships between Integrator Involvement, Grower Involvement and business performance.

\section{Material and Methods}

General approach of this research is quantitative. With regard to the research problem which try to study the relationship between integrator involvement, grower involvement towards business performance. Furthermore if there, any moderating effect managerial skills level between independent variable and dependent variable. It performed based on survey strategy and it is appreciating of descriptive-analytical method. Statistical of this research consisted of all industry broiler production businesses (growers) selected as statistical sample.

This study was conducted in Peninsular Malaysia. The businesses that responded were from Kedah (33.3\%), Pulau Pinang (14.7\%), Perak (28.1\%), Selangor (0.4\%), Negeri Sembilan (14\%), Melaka (1.4\%), Kelantan (5.6\%), Terengganu (0.4\%) and Pahang (0.7).This chapter first presents descriptive statistics based on the data collected from 
the surveys. The responding companies' background information will be analyzed, followed by statistical analysis of the data and discussion of the results with regards to the hypotheses testing.

The total respondents were 285:which translates to the following percentages of the categories mentioned besides each; 64.2 percent farm owners, 1.8 percent general manager, 1.4 percent managing directors, 5.6 percent managers, 20.4 percent senior managers and others (managerial position) 6.7 percent. The number of years in that particular position includes the range of 1 to 5 years 19.5 percent, 6 to 10 years 37.9 percent, 11 to 15 years 27.7 percent, 16 to 20 years 9.8 percent and more than 20 years 5.3 percent. The percentage of businesses with permanent employees: less than 50 (89.5\%); 50 to 100(6.7\%); 100 to 150 (3.2\%) and more than $150(0.7 \%)$.The two types of housing included: Closed House System (CHS) 55.4\%; and Conventional System (CS) 44.6\%. The average sale percentage of the businesses for last three years is; up to RM1, 000,000 (88.41\%), RM1, 000,001 to RM2, 000,000 (11.2\%); and over RM2, 000,000 (0.4\%).The average profit percentage of the businesses for last three years is; up to RM100, 000 (96.1\%),; and over RM100,000 (3.9\%).The businesses from states in Peninsular Malaysia.

Specifically designed questionnaire was the instrument used for data collection. A set of attributes was included in the questionnaire that encompassed the grower and integrator involvement, grower managerial skills, and grower business performance question about broiler production and professional characteristics. To ensure its content and face validity, the research instrument was reviewed several times by the research group (Research Department, Department of Veterinary Services of Malaysia) and then implemented in a pilot test to measure its reliability. Questionnaire reliability was estimated by calculating Cronbach's alpha. Reliability for each variable is explained below:

\subsection{Factor Analysis Results}

Dependent Variable - Business Performance (BP) Table-1 shows the result of factor analysis for business performance. The total items measuring this dimension were 15 items. However, after considering all the criteria discussed before, the factor analysis produced two factors and maintained twelve items. Three items were deleted because failed to meet the criteria mentioned above. As shown in Table-1, all items have factor loadings above 0.50 on two factors and 0.35 or lower on the other factor. From the factor analysis indicates that all show items are valid and reliable. Factor component one namely business performance financial comprised of six items and component two namely business performance non-financial comprised of six items.

\subsection{Result of the Factor Analysis of Business Performance}

Table 1. Rotated Component Factor Matrix ${ }^{\mathrm{a}}$

\begin{tabular}{lll}
\hline \multicolumn{3}{c}{$\begin{array}{c}\text { Rotated Component Factor Matrix } \\
\text { Component }\end{array}$} \\
& 1 & 2 \\
\hline EBP62 & .850 & \\
EBP58 & .806 & \\
EBP59 & .768 & \\
ENF72 & .720 & \\
EBP60 & .720 & \\
EBP61 & .686 & .771 \\
ENF63 & & .749 \\
ENF65 & & .735 \\
ENF70 & & .724 \\
ENF69 & & .716 \\
ENF64 & & .656 \\
ENF71 & & \\
\hline
\end{tabular}

The eigenvalues for factor was greater than one. The Kaiser-Meyer-Olkin (KMO) value was .789 and Bartlett's test of sphericity was significant. The one factor extracted from the factor analysis was named business performance (BP). 
The factor was defined by 12 items related to business performance. It includes cost of production, sales revenue, profitability and return on investment for financial. Whereas non-financial includes; delivery speed, rework rate, retained customers, product reliability, production cycle, and customer relation.

\subsection{Independent Variable - Integrator Involvement in Product Innovativeness (PI)}

Integrator involvement in product innovativeness (PI) had one dimension. The total items measured were 8 . This dimension was analyzed using factor analysis to check for their validity. Using most of the criteria discussed before, the analysis extracted one dimension. In the process of getting this one dimension, six items had to be removed due to low communality value. Retained items include; producing new birds for your customer from time to time is very important, created new method to marketing system for broiler is a crucial, and creating new technology for how to grow broiler from time to time are very important.

\subsection{Result of the Factor Analysis for Integrator Involvement in Product Innovativeness}

Table 2. Rotated Component Factor Matrix

\begin{tabular}{cc}
\hline \multicolumn{3}{c}{ Rotated Component Factor Matrix } \\
\hline \multicolumn{3}{c}{ Factor } \\
\hline PI2 & .720 \\
PI3 & .843 \\
PI4 & .718 \\
\hline
\end{tabular}

\subsection{Independent Variable - Integrator Involvement in Product Modularity (PM)}

The second independent variable was integrator involvement in product modularity and consists of 5 items. Based on the factor analysis two items were deleted because they did not fulfil the requirement of .50. Retained items includes; like the other product, broiler also can be separated into parts such as special cutting, and broiler can be produced according to size and weight that is required without making changes in the feeding composition.

6.6 Result of the Factor Analysis for Integrator Involvement in Product Modularity

Table 3. Rotated Component Factor Matrix

\begin{tabular}{cc}
\hline \multicolumn{2}{c}{ Rotated Component Factor Matrix } \\
Factor \\
\hline PM3 \\
PM4 & .815 \\
PM5 & .665 \\
\hline
\end{tabular}

\subsection{Independent Variable - Integrator Involvement in Internal Coordination (IC)}

The third independent variable was integrator involvement in internal coordination and it consists of 9 items. Based on the factor analysis in Table 4, items number IC1, and IC6 were deleted because they did not fulfil the requirement of .50. These items include; Integrator and grower are always sharing the data, Integrator and grower are always practice teamwork, implementing activities together and close coordination, implementing close coordination in product design \& development, were interactive system between production division and sales division, have close coordination in product launching, and have integrated inventory management.

Therefore, by using only 7 items out of 9 items is good enough to answer the whole dimension of integrator involvement in internal coordination. The 7 of the items sits accordingly in factor one with factor loadings more than .5. It can be concluded all the items fall under one factor. 
6.8 Result of the Factor Analysis for Integrator Involvement in Internal Coordination

Table 4. Rotated Component Factor Matrix

\begin{tabular}{ll}
\hline \multicolumn{2}{c}{$\begin{array}{c}\text { Rotated Component Factor Matrix } \\
\text { Factor }\end{array}$} \\
\hline IC2 & .768 \\
IC3 & .735 \\
IC4 & .738 \\
IC5 & .785 \\
IC7 & .754 \\
IC8 & .736 \\
IC9 & .721 \\
\hline
\end{tabular}

The eigenvalues for factor was greater than one. The Kaiser-Meyer-Olkin (KMO) value was .907 and Bartlett's test of sphericity was significant. The one factor extracted from the factor analysis was named integrator involvement in internal coordination (IC).

6.9 Independent Variable - Grower Involvement (GI)

The fourth independent variable was grower involvement which consists of 5 items. Factor analysis shows the result of factor analysis for grower involvement; the total items measuring these dimensions were 5 . However, after considering all the criteria discussed before, the factor analysis produced only one factor. One item, GI1 was deleted because it fails to meet the criteria mentioned above.

6.10 Result of the Factor Analysis for Grower Involvement

Table 5. Rotated Component Factor Matrix

\begin{tabular}{cc}
\hline \multicolumn{2}{c}{ Rotated Component Factor Matrix } \\
Factor \\
\hline GI2 & .797 \\
GI3 & .810 \\
GI4 & .783 \\
GI5 & .772 \\
\hline
\end{tabular}

As shown in Table-3, all items had factor loadings above .50 on one factor and .35 or lower on the other factor. Four items fulfill the requirement of .5. The factor was defined by 4 items related to grower involvement. It includes; joint process engineering (e.g. drinking system), joint production operation, joint marketing method (e.g. grade and price), and joint transport information (e.g. own transport, outsource). The eigenvalues for factor was greater than one. The Kaiser-Meyer-Olkin (KMO) value was .907 and Bartlett's test of sphericity was significant. The one factor extracted from the factor analysis was named grower involvement (GI).

Moderating Variables - Managerial Skills (MS) Table-4 shows the results of factor analysis for managerial skills (MS). At the beginning, the moderating variable was measured by 30 items in one dimension. The variable has 5 dimensions. It comprised; i) Planning and goal setting skills, ii) Accountancy and financial management skills, iii) Marketing and management skills, iv) Information seeking skills, and v) Decision making skills. Planning and goal setting skills which is has 6 items. On the other hand, the Bartlett's test of sphericity is statistically significant, supporting the factorability of the correlation matrix, as the p-value is 0.00 . This indicated the adequacy of applying the factor analysis. The three factor extracted from the factor analysis was named managerial skill (MS).

Table-4 shows four items were deleted from Planning and goal setting skills. These are DGM1.1, DGM1.4, DGM1.5 and DGM1.6. Retained items include; ability to develop production program and to identify production targets in the short and long term and having a program for hard and difficult conditions and following it.

Accountancy and financial management skills has 8 items Based on the factor analysis in Table-4 shows four items; DGM2.5, DGM2.6, DGM2.7, and DGM2.8 in this dimension were deleted because they did not fulfill the requirement of .50 . 
Retained items include ability to record the activities in broiler production period, ability to record consumed inputs in broiler production, ability to record and calculate the amount of initial capital in broiler production, and ability to record and calculation of profit and loss in broiler production.

Marketing and management skills has 6 items Based on the factor analysis in Table-4, four items in this dimension were deleted because it they did not fulfill the requirement of .50. Deleted items were DGM3.1, DGM3.2, DGM3.3 and DGM3.4. Retained items include; ability to analyze government policy on broiler market, and ability to supply product directly to consumers (rather than selling to slaughterhouse).

Information seeking skills has 4 items. Based on the factor analysis in Table-4, all items in this dimension were retained based of fulfillment of the requirement of .50. Items were; ability to find for new and better way to improvements, ability to collect information about new production technologies, ability to collect information on inputs, prices, and market, and ability to collect information about government policies on the market.

Decision making skills has 6 items. Table- 4 shows the result of factor analysis for dimension decision making skills in the variable managerial skills. The total items measuring these dimensions were 6 . However, after considering all the criteria, as shown in Table-4, five items had factor loadings above .50 on one factor and .35 or lower on the other factor. Retained items in this dimension were; ability to make decision about technologies to used or be accepted, ability to effective use from livestock advisors (economical, veterinary, nutrition, etc.), ability to use best management operations broiler production units, ability to take right decisions about time or acceptance of new technologies, and ability to quickly identify and correct farming problems and the principles to solve the problems.

These show 17 items are valid and reliable. The eigenvalues for factor was greater than one. The Kaiser-Meyer-Olkin (KMO) value was .921 exceeding the benchmark value of 0.60, this implied that, the sample size is adequate for factor analysis to be conducted. Also, the ratio of the sample size to the number of items is sufficient for factorability.

6.11 Result of the Factor Analysis of Managerial Skills

Table 6. Rotated Component Matrix

\begin{tabular}{cccc}
\hline \multicolumn{3}{c}{ Rotated Component Matrix } \\
& \multicolumn{3}{c}{ Component } \\
\hline & 1 & 2 & .788 \\
\hline DGM1.2 & & & .808 \\
DGM1.3 & & .885 & \\
DGM2.1 & & .879 & \\
DGM2.2 & & .825 & \\
DGM2.3 & & .785 & \\
DGM2.4 & & & \\
DGM3.5 & .777 & & \\
DGM3.6 & .751 & & \\
DGM4.1 & .759 & & \\
DGM4.2 & .824 & & \\
DGM4.3 & .716 & \\
DGM4.4 & .765 & \\
DGM5.1 & .739 & \\
DGM5.2 & .761 & \\
DGM5.3 & .796 & \\
DGM5.4 & .754 & \\
DGM5.5 & .629 & \\
\hline
\end{tabular}




\subsection{Cronbach's Alpha for Each Variable under Study}

The purpose of this reliability analysis is to ensure internal consistency of measurements of the items. The scale of internal consistency becomes an issue when the items that make up the scale hang together or not. The most common indicator of internal consistency is Cronbach's Alpha coefficient. Ideally, the Cronbach's Alpha7 of a scale should be 0.7 . The table- 5 below shows the Cronbach's Alpha for each variable under study.

\subsection{Cronbach's Alpha for Each Variable under Study}

Table 7. Cronbach's Alpha

\begin{tabular}{llll}
\hline Type of variable & Dimension & No. of Items & Cronbach's Alpha \\
\hline Dependent variable & Business Performance & & \\
& Financial & 5 & 0.903 \\
& Non-Financial & 6 & 0.771 \\
Independent variable & Product Innovativeness & 3 & 0.84 \\
& Product Modularity & 3 & 0.715 \\
& Internal Coordination & 7 & 0.928 \\
Moderator & Grower Involvement & 4 & 0.911 \\
& Planning and Goal Setting & 2 & 0.671 \\
& Accountancy and Financial & 4 & 0.912 \\
& Management Skills & & \\
& Marketing Management & 2 & 0.947 \\
& Skills & & \\
& Information Seeking Skills & 4 & \\
& Decision Making Skills & 5 & \\
\hline
\end{tabular}

The above Cronbach's alpha shows that the index had high reliability. The data were collected between April and July 2013. These questionnaires were delivered to all businesses in all states and collected through mail. In order to measure the perspective of broiler production about integrator involvement, grower involvement, managerial skills and business performance, 72 questions, excluding profiles questions, were used to measure respondent perspective in each; in broiler production businesses, 5 point scale had been ranked from 1 = very low, 2 = low, 3 = moderate, 4 $=$ high to $5=$ very high. In order to analyze data; descriptive statistic (mean and standard deviation) and inferential methods (Friedman test) were used.

\section{Expected Contributions}

The study is expected to provide a much needed latest empirical insight into the Malaysian broiler industry. The content validity has been done by getting opinion from the experts namely Veterinary officers. Besides that the construct reliability is determined through value from Cronbach Alpha. The data obtained was satisfactory for content validity and construct validity and also fit the model as proposed previously.

\section{Conclusion}

The study proposes an empirical investigation over the relationships between supplier involvement, customer involvement and business performance in the poultry industry. The scope of the research is the Malaysian local poultry industry. The content validity has been done by getting opinion from the experts namely Veterinary officers. Besides that the construct reliability is determined through value from Cronbach Alpha. The data obtained was satisfactory for content validity and construct validity and also fit the model as proposed previously. A research framework and goals are advocated in relations to the above matter. Upon completion, the research is expected to be beneficial for relevant policy makers thirsts need to have some empirical evidence on the supply chain practices in local poultry industry. 


\section{References}

Athaide, G. A, \& Klink, R. R. (2009). Managing seller-buyer relationships during new product development. Journal of Product Innovation Management, 26, 566-577. http://dx.doi.org/10.1111/j.1540-5885.2009.00681.x

Brown, S. L., \& Eisenhardt, K. M. (1995). Product development: past research, present findings, and future directions. Academy of Management Review, 20(2), 343-378.

Calantone, R. J., Chan, K., \& Cui, A. S. (2006). Decomposing product innovativeness and its effects on new product success. Journal of Product Innovation Management, 23, 408-421. http://dx.doi.org/10.1111/j.1540-5885.2006.00213.x

Clark, K. B., \& Fujimoto, T. (1991). Product Development Performance. Boston, M A.: Harvard University Press.

Cooper, R. G., \& Brentani, U. D. (1991). New industrial financial services: what distinguishes the winners. Journal of Product Innovation Management, 8(1), 75-90. http://dx.doi.org/10.1016/0737-6782(91)90002-G

Cooper, R. G. (1979). The dimensions of industrial new product success and failure. Journal of Marketing, 43, 93-103. http://dx.doi.org/10.2307/1250151

Daft, R. I., \& Marcic, D. (2001). Understanding management (3rd ed.). Fort worth, USA: Harcourt College Publishers.

Danneels, E., \& Kleinschmidt, E. J. (2001). Product innovativeness from the firm's perspective: its dimensions and their relation with project selection and performance. Journal of Product Innovation Management, 18, 357-373. http://dx.doi.org/10.1016/S0737-6782(01)00109-6

Droge, C., Jayaram, J., \& Vickery, S.K. (2004). The effects of internal versus external integration practices on time-based performance and overall firm performance. Journal of Operations Management, 22(6), 557-73. http://dx.doi.org/10.1016/j.jom.2004.08.001

Feng, T, L. Sun, \& Zhang, Y. (2010). The effects of customer and supplier involvement on competitive advantage: an empirical study in China. Industrial Marketing Management, 39(8), 1384-1394. http://dx.doi.org/10.1016/j.indmarman.2010.04.006

Fliess, S, \& Becker, U. (2006). Supplier integration - controlling of co-development processes. Industrial Marketing Management, 35, 28-44. http://dx.doi.org/10.1016/j.indmarman.2005.07.004

Garcia, R, \& Calantone, R. (2002). A critical look at technological innovation typology and innovativeness terminology: a literature review. The Journal of Product Innovation Management, 19, 110-132. http://dx.doi.org/10.1016/S0737-6782(01)00132-1

Gerwin, D, \& Barrowman, N. J. (2002). An evaluation of research on integrated product development. Management Science. 48(7), 938-953. http://dx.doi.org/10.1287/mnsc.48.7.938.2818

Grant, R. M. (1996). Prospering in dynamically-competitive environments: organizational capability as knowledge integration. Organization Science, 7(4), 375-387. http://dx.doi.org/10.1287/orsc.7.4.375

Griffin, A. (2002). Product development cycle time for business-to-business products. Industrial Marketing Management, 31, 291-304. http://dx.doi.org/10.1016/S0019-8501(01)00162-6

Hargadon, A. B, \& Eisenhardt, K. M. (2000). Speed and quality in new product development. In Cole, R.E. and Scot, W.R. (Eds.), The Quality Movement Organization Theory. Sage, New York, NY.

Ittner, C. D., \& Larcker, D. F. (1997). Product development cycle time and organizational performance. Journal of Marketing Research, 34(1), 13-23. http://dx.doi.org/10.2307/3152061

Kaplan, R. S., \& Norton, D. P. (1992). The Balanced Scorecard-Measures that Drive Performance. Harvard Business Review, 71-79.

Key, N., \& Runsten, D. (1999). Contract farming, smallholders and rural development in Latin America: the organization of agro processing firms the scale of out grower production. World Development, 27(2), 381-401. http://dx.doi.org/10.1016/S0305-750X(98)00144-2

Kleinschmidt, E. J., \& Cooper, R. G. (1991). The impact of product innovativeness on performance. Journal of Product Innovation Management, 8, 240-251. http://dx.doi.org/10.1016/0737-6782(91)90046-2

Lau, A.K.W. (2011). Supplier and customer involvement on new product performance Contextual factors and an empirical test from manufacturer perspective. Industrial Management \& Data Systems, 111(6), 910-942. 
http://dx.doi.org/10.1108/02635571111144973

MyCC. (2012). Malaysia Competition Commission ("MyCC”) - Review of Domestic Broiler Market: Interim Report.

O'Raily, M., Wathey, D., \& Gelber, M. (2000). ISO 14031: Effective mechanism to environmental performance

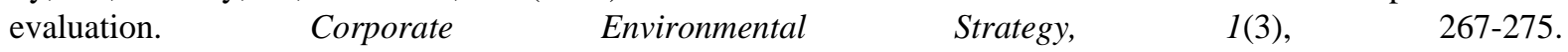
http://dx.doi.org/10.1016/S1066-7938(00)80121-9

Ragatz, G. L., Handfield, R. B., \& Scannell, T. V. (1997). Success factors for integrating suppliers into new product development. Journal of Product Innovation Management, 14, 190-202. http://dx.doi.org/10.1016/S0737-6782(97)00007-6

Schilling, M. A. (2000). Toward a general modular systems theory and its application to inter-firm product modularity. Academy of Management Review, 25(2), 312-334.

Song, M. X., \& Montoya-Weiss, M. M. (1998). Critical development activities for really new versus incremental products. Journal of Product Innovation Management, 15(4), 124-135. http://dx.doi.org/10.1016/S0737-6782(97)00077-5

Song, M. X., \& Parry, M. E. (1997). A cross-national comparative study of new product development processes: Japan and the United States. Journal of Marketing, 61, 1-18. http://dx.doi.org/10.2307/1251827

Song, X. M., \& Benedetto, A. D. (2008). Supplier's involvement and success of radical new product development in new ventures. Journal of Operations Management, 26(1), 1-22. http://dx.doi.org/10.1016/j.jom.2007.06.001

Takeishi, A. (2001). Bridging inter- and intra-firm boundaries: management of supplier involvement in automobile product development. Strategic Management Journal, 22(5), 41-53. http://dx.doi.org/10.1002/smj.164

Tan, C.L., \& Tracey, M. (2007). Collaborative new product development environments: implications for supply chain management. Journal of Supply Chain Management, 43(3), 2-15. http://dx.doi.org/10.1111/j.1745-493X.2007.00031.x

Ulrich, K. (1995). The role of product architecture in manufacturing firm. Research Policy, 24(3), 419-440., http://dx.doi.org/10.1016/0048-7333(94)00775-3

Van Echtelt, F. E. A., Wynstra, F., Weele, V. A. J., \& Duysters, G. (2008). Managing supplier involvement in new product development: a multiple-case study. Journal of Product Innovation Management, 25, 180-201. http://dx.doi.org/10.1111/j.1540-5885.2008.00293.x

Zack, M., McKeen, J., \& Singh, S. (2009). Knowledge management and organizational performance: an exploratory analysis. Journal of Knowledge Management, 13(6), 392-400. http://dx.doi.org/10.1108/13673270910997088

Zhao, X., Huo, B., Selen, W., \& Yeung, J.H.Y. (2011). The impact of internal integration and relationship commitment on external integration. Journal of Operations Management, 29(1/2), 17-32. http://dx.doi.org/10.1016/j.jom.2010.04.004

Zirger, B. J., \& Hartley, J. L. (1994). A conceptual model of product development cycle time. Journal of Engineering \& Technology Management, 11, 229-251. http://dx.doi.org/10.1016/0923-4748(94)90011-6

Zirger, B. J., \& Maidique, M. A. (1990). A model of new product development: an empirical test. Management Science, 36(7), 867-883. http://dx.doi.org/10.1287/mnsc.36.7.867 